\title{
The Effectiveness of Group Counseling Model through The Behavioral Rehearsal Approach to Overcome Student Social Anxiety
}

\author{
Muhammad Ilham Bakhtiar ${ }^{1)}$, Rahmatia ${ }^{2)}$ \\ 1), 2) Guidance and Counseling STKIP Andi Matappa Pangkep \\ E-mail: Ilhambakhtiar86@gmail.com
}

\begin{abstract}
This study aims to find out: (1) the development of group counseling models through the approach Behavioral Rehearsal to overcome Student social anxiety, (2) To find out whether the group counseling model through the approach is Behavioral Rehearsal effective for dealing with students' social anxiety. The method used in the research is Research and development (R \& D). The target of this research is the students of Pangkajene 2 State High School in Pangkep Regency. The targeted output of this study is that this study produced a group counseling model Behavioral Rehearsal to overcome students 'social anxiety and effectiveness in overcoming students' social anxiety. This model is the result of the need in the Pangkajene Superior 2 State High School which will later be used as the basis for the development of protype to help students overcome social anxiety problems. Then the results of the prototype will be a draft guide and published in the seminar forum in the form of proceedings. The results of the draft from protype development were then validated by experts (expert guidance and counseling and psychology) and practitioners as users of this group's counseling model. In addition, this year also will test the effectiveness of the product on the group's product or model of counseling to students. Research results will be published in nationally accredited scientific journals and published through proceedings through national seminars. The results of the study were (1) the school experienced problems related to research studies, then the condition of the school that was maximal applied group counseling especially using approaches and in school there were various problems of social anxiety then group counseling activities were carried out with five sessions. (2) The results of the expert validation test stated that this guide was suitable to be used (3) the results of the percentage analysis explained that there was a decrease in value after the group counseling activities with a behavioral rehearsal approach.
\end{abstract}

Keywords: Group counseling; Behavioral rehearsal; Social anxiety

\section{INTRODUCTION}

Students as social individuals in fulfilling their needs do a social interaction in their environment, including teenagers. (Izzaty, 2008: 3). In addition, according to Ali \& Asrori (2006: 9) adolescents engage in social interaction as well as part of their development in the search for identity. Another thing is that not all individuals in adolescent age can comfortably interact with their social environment (Mutahari, 2016). These individuals tend to be worried and afraid of negative perceptions of the environment towards themselves. This is what according to (Stefan G. Hofmann, 2010) is said to be social anxiety.

This anxiety disorder occurs in adolescence. Research conducted (Mutahari, 2016) explains that anxiety in students who are teenagers occurs when students meet new friends, new teachers, and new school rules that must be adhered to, some students are also embarrassed when interacting with others, and often students are embarrassed just to speak in front of the class.

It is clear that the cause of social anxiety in students is when teens are in a new environment. One of the causes of social anxiety in students is when individuals enter a new situation and require new 
adjustments to the situation (Grecal \& Lopezl, 1998). In this case, physically, there is a major change along with the puberty experienced. Cognitively, there is a fundamental change in intellectual ability (Moshman, 2005). and requires adjustments that are new to the situation (Greca and Lopezl, 1998: 88). Cognitively, there is a fundamental change in intellectual ability (Moshman, 2005). Then right on the world mental day October 2016, Wahyuningsing (2016: 179) explained that the level of mental illness that is increasingly rampant including Social Anxiety Disorder is also called social phobia. This disorder is an anxiety disorder where a person feels excessive fear of being in a social environment for no apparent reason. This anxiety is realized arising from a feeling of fear of being observed, said, and criticized by others. Symptoms experienced by people with this disorder include: The intensity of anxiety every time you are in a crowd, avoiding crowds or the social environment, physical symptoms such as rapid heartbeat, sweating, trembling, excessive shyness, tense muscles, aching stomach, or even until diarrhea.

Based on the results of preliminary observations at the target location of the Pangkajene Superior 2 State High School, the BK teacher stated that there were many problems related to students' social anxiety in this school, this was because students from different backgrounds had prestige as a superior school so students from the region feel this. So that the form of anxiety that arises is a feeling of fear of being observed outside the class, being said / bullied, avoiding the crowd, shy and anxious.

Students can be in a safe environment, get a good group position, are more likely to always interact with the social environment so that it is easy to achieve learning achievement. This anxiety is caused by the existence of individual behavior that is a problem so that it needs proper handling through behavioral change. Behavioral change aims to change observable and measurable human behavior. (Palmer.2010). these changes are chosen according to the needs of the problems faced by students in order to see behavior changes. One technique as behavioral therapy is behavioral rehearsal.

Behavioral rehabilitation is one of many techniques derived from behavioral therapy according to Thorpe \& Olson (Brandle T. Elford: 2016). The technique of behavioral therapy was originally called behavioristic psychodrama (behavioristic psychodrama), a mixture of conditioned therapy reflex (conditioned reflexes) from salter, psychodrama techniques from Moreno and fixed role therapy (permanent role therapy) from Kelly (Elford: 2016). But more often used is the behavior rehearsal (rehearsal / rehearsal behavior) with clients that need to be fully aware of him.

Giving rehearsal behavior in the form of training.techniques are Rehearsal behavior applied in the form of role playing where clients learn a new type of behavior outside of the counseling situation. Behavior Rehearsal includes several key components: imitating behavior, receiving feedback from counselors, and often practicing / practicing desired behavior (Elford: 2016). Efforts are carried out together in one group, with the aim of providing a shared learning experience in handling the anxiety problem. Thus explained Walsh (2002) found a technique of rehearsal behavior useful when dealing with people who experience social anxiety. In addition Hackney \& Cormie (2012) explained that this technique succeeded in creating changes in attitudes in students, and changes in certain targeted behaviors.

Thisapplication behavioral rehearsal is in the form of group counseling. Counseling as aheping profession, as a helping professional, counseling is carried out with various procedures, one of which is through group procedures (Kurnanto, 2013). Group counseling can provide individuals with various group experiences that help them learn effectively, develop tolerance for stress and anxiety, and find satisfaction in working and living with others (Corey, 2012).

Efforts madetechniques rehearsal behavior bywith group counseling will provide learning experiences that can change students' behavior as target subjects in this study.

Group counseling as a service that can prevent or improve both in the personal, social learning and career fields. In addition Corey (2012) also explained that group counseling can provide individuals with various group experiences that help them learn effectively, develop tolerance for stress and anxiety, and find satisfaction in working and living with others. Based on the description above, the researchers are interested in researching "Development of Group Counseling Models through approaches Behavioral Rehearsal to Overcoming Social Anxiety of State High School Students 2 Excellent Pangkajene"

\section{METHODOLOGY}

Type of research is development research using the development strategy model proposed by Borg and Gall (2003) this strategy was chosen because the implementation steps were clear besides that this development strategy consisted of a more detailed and systematic development cycle whose development cycle through product development, testing the product in the field, revising, re-testing in the field, revising until the product was right true in accordance with the expected development goals. The steps are as follows: (1) Research and collection of information, (2) Planning, (3) Initial product development, (4) Initial field test, (5) Revision of main products, (6) Main field test, ( 7) Revision of 
operational products, (8) Operational field testing, (9) Final product revision and (10) Decrease and implementation. This strategy is called research and development(Reseach and development), which is a cycle of development that consists of 10 steps of development. In this study not all steps were carried out, but more tailored to the needs. Starting from predevelopment, development and post-development.

To capture various types of information from various sources, various methods and data collection tools will be used as follows: Interviews and Questionnaires or questionnaires

Validation and Data Analysis The

use of validity in this study emphasizes content Validity, which is the validity that indicates the extent of the item. items in the test cover the entire content area to be measured. Reliability is how far the measurement results can be trusted. In principle, reliability shows how far a measurement can provide results that are not different if the measurement is done again on the same subject (Tuckman, 1999). Calculation of validity and reliability using the SPSS version 20.0 program.

Data analysis of this study uses qualitative and quantitative descriptive analysis. Data analysis will also include continuous reflective analysis (revision process) during the process of developing a behavioral rehearsal group counseling model to overcome student anxiety. To see the effectiveness of the behavioral rehearsal counseling model, conducted t-test was to compare groups before and after the counseling model of behavioral rehearsal groups given to students (Tuckman, 1999).

\section{RESULTS AND DISCUSSIONS}

\section{Development of group counseling models throughapproach Behavioral Rehearsal to overcome Students' Social Anxiety in Pangkajene 2 High School}

In developing this module, there are several steps to formulate a group counseling model through a Rehearsal behavior approach, namely the stages as follows

\section{a. Needs analysis}

The process of preparing group counseling guidelines through rehearshal behavior approach begins with a need assessment or needs analysis activities for students and teachers at school. The needs analysis activity aims to get an earlier picture of group counseling through rehearshal behavior to overcome students' social anxiety. Then the needs assessment is directed to obtain an overview of the needs of the form of group counseling through a rehearsal behavioral approach needed in the handling of students' social anxiety in schools, then problems related to social anxiety problems that occur in schools and the forms of services that have been provided by teachers in the existing problems.

Based on the survey results to make direct observations at school, it was found that problems related to social anxiety often occur such as embarrassment to associate with peers, anxiety occurs whenever you are in a crowd, avoiding crowds or social environment, physical symptoms such as heart pounding, sweating, shaking, excessive shyness, tense muscles, aching stomach. The BK teacher said that there are many problems related to students' social anxiety in this school, this is because students who come from different backgrounds, there is prestige as a superior school so students who come from the region feel this. So that the form of anxiety that arises is a feeling of fear of being observed outside the class, being said / bullied, avoiding the crowd, shy and anxious.

Then the type of counseling that is mostly given is still more to individual counseling, handling is more preventive, follow-up social problems sometimes involve students and parents. The maximum counseling that has been given is in the form of changes in certain behaviors or approaches of each problem given, such as this rehearsal behavior approach.

\section{b. Model Development}

From the results of the needs analysis, the researcher gets an overview of the problems that occur, then the researcher conducts a literature study in assessing the problems and approaches to be used. The literature study of the main material is a approach rehearsal behavioral to overcome students' social anxiety, both regarding the technique, stages, purpose of benefits and the strategy of practicing the technique.

Referring to the needs analysis and literature study, a model with the name of the "counseling guide is behavioral rehearsal"designed to overcome students' social anxiety. This guide is applied in the form of group activities, practices by breathing deeply to relieve yourself or relax yourself in order to owe students' social anxiety. Expert guidance has been compiled.

1) Validation Expert

expert validation in the study was intended to assess acceptability of form and content The group counseling guide book "Rehearshal Behavior" addresses students' social anxiety that will be used as training material and practice in dealing with social anxiety, namely deep breathing or deep breathing relaxation. Expert trials are provided to lecturers for guidance and counseling. Expert test subjects selected based on the criteria: Selection of expert try subjects is to have a degree at least is someone concerned educated in the field of guidance and counseling. Expert test subjects were asked to assess the acceptability level of the Counseling guide guide the group "Rehearshal Behavior" to overcome 
students' social anxiety, which included: usefulness, feasibility and accuracy. The trial was conducted by giving an assessment questionnaire to this training model to BK lecturers.

Expert validation assessment with an assessment questionnaire in the form of a scale (1-2$3-4)$. Each number is given the following meaning, not useful / inappropriate / not feasible / unnecessary / not clear (given number 1), less useful / less precise / less feasible / less necessary / less clear (given number 2), useful / appropriate / feasible / necessary / clear (number 3 ), and very useful / very appropriate / very feasible / very necessary / very clear (given number 4). Data obtained from these expert tests are quantitative and qualitative. Quantitative data acquisition is captured using an assessment questionnaire given to each expert. While qualitative data in the form of comments, criticisms, suggestions for improvement obtained from the results of expert discussions. The data is used as consideration for revising the guidelines and to assess the acceptability of this guide which is reviewed from three aspects, namely usability, feasibility and accuracy, before being tested on students.

Expert test results indicate that in general the assessment of the Counseling Guidance lecturers on this book both through questionnaires and discussions is good, meaning that this guide is feasible and acceptable to be used as a training guide for students in overcoming social anxiety. This can be seen from the distribution of values from the three criteria made in terms of usability, feasibility, and accuracy, where the average score is at level 3 and 4. It can be concluded that this guide is acceptable, but this guide needs to be refined. to further improve the quality of the guide. Therefore the input from expert lecturers was highly respected by researchers for the perfection of the guidelines compiled.

Expert test activities continued with discussion and commenting, which can be seen in full below:

a) Validator I Lecturer BK (Hasbahuddin S. Pd. M.Pd)

Comments from validator I convey that the guide needs to improve writing techniques, the cover is attempted to be more interesting, choose an image that stimulates positive psychology, the appearance or content is more interesting so students like to read and see.

b) Validator II Lecturer BK (Salmiati, S.Pd. M.Pd) Comments from validator II convey that complete with interesting drawings in the material section and guidance instructions, the steps of this technical practice instruction are more simplified sentences so that students can quickly understand when read or used by this guide, clarifying the guided worksheet An

\section{Overview of the application of counseling Behavioral Rehearsal}

The implementation of treatment activities to overcome social anxiety through the approach Behavioral Rehearsal given to students was agreed upon during the meeting. During the implementation of this activity, the researcher himself became the activity coordinator as well as the leader in this activity.

Following are the steps for implementing the approach Behavioral Rehearsal to overcome students' social anxiety;

a. Pra-sesion of research activities

Beginning the activities of the researchers to coordinate with the school, namely the school principal and guidance teachers and counseling regarding the implementation of this activity. Then the class is agreed upon and the number of students to be targeted by the research sample.

At the same time the researchers gave a questionnaire as a pre-test to the two study groups. Before being implemented, the researcher first explains the purpose and purpose of giving the questionnaire. The purpose of giving the questionnaire is to get a picture of the level of social anxiety experienced by students before counseling through the approach Behavioral Rehearsal to the experimental group.

b. First session.

The first session was held in the student class. The researcher built a good relationship with all students then explained the general picture about the approach Behavioral Rehearsal. Before starting the activity, the researcher first asks students about their readiness to participate in this activity, and explains the time needed in each of these activity meetings.

When describing their readiness to participate in this activity, researchers begin to build relationships with students through introductions between students and researchers and vice versa, then continued conversations that can build students' awareness, and their position in their place is very important for them. Researchers do simple exercises so that students are not bored and bored in participating in this activity. Students as participants are in a circular form following the instructions of the researcher.

Enter the identification phase of the problem. The researcher then explains in general to students, why anxiety can occur in students. This explanation aims so that the rest can find out the factors and causes of social anxiety in students. This stage the researcher then performs the interaction process with students by describing the initial data of the Pre-test results that have been filled by students. From the data, the researcher emphasizes that the problems they face can be done through the approach, Behavioral Rehearsal which is by doing exercises or behavior change changes. Then this explanation will give hope 
to students to be able to change so that students feel that the problems that occur to him are things that can be changed and can be overcome.

After being given an explanation the researcher then gave an exercise in the implementation phase of the approach Behavioral Rehearsal to students. The application of this approach through basic breathing techniques. Yes, this technique is an exercise directly or medically on anxiety handling instructions. The form of exercise is to use deep breathing / abdominal breathing. Abdominal breathing, also called diaphragmatic breathing, is the process of breathing by breathing deeply so that the body receives enough oxygen. The steps are:

1) Participants are asked to take a sitting position

2) Participants must be sure of themselves that they are relaxed in that position

3) Inhale slowly. Let the air fill your lungs, and before your lungs are full, hold your breath for a while, do not immediately exhale.

4) Let your stomach expand. When you take a deep breath, let your stomach expand two to four inches. Air will flow into the diaphragm, so your stomach will expand because it is filled with air.

5) Exhale until it's gone. Let your breath come out through your mouth or nose. When you exhale, pull your stomach toward the spine and remove air from your lungs until it runs out. After you exhale, take a deep breath again through your nose and continue to breathe deeply. Try to exhale twice as long as your breath, and remove the air until it runs out.

6) Try breathing five times in a row. This method will immediately calm down by making the heart beat steady, and make blood pressure normal again, and divert your mind from thoughts that trigger anxiety on yourself.

The first training session was carried out 5-10 times over and over, and was guided directly by researchers. The participants were very enthusiastic in participating in this exercise, it appeared with a feeling and a calm class atmosphere. When completing this first session the researcher asks participants to compare feelings before doing this technique and after doing this technique. At the end of the meeting participants were given a challenge in the form of tasks to do at home 3 (three) times a day, morning, afternoon and night before bed. Monitoring of the implementation of the challenge is recorded on the control card that has been distributed.

\section{c. Second Session}

At this second meeting, this phase began with the researcher reflecting on the progress of the previous meeting. researchers and students explore feelings that are felt, changes and situations that occur after carrying out the first stage. The researcher then reexplained that the importance of being in a social environment without pressure, and could improve student learning achievement.

Researchers explore students who complete the first challenge at home. Participants compare and see the progress in themselves towards the emergence of feelings of anxiety in themselves. The control card that has been filled by students is used as a reflective material in expressing the feelings felt by students. The occurrence of these changes is due to regularly carrying out this exercise / rehearsal at home.

The activity at this stage participants were asked to do approach to Behavioral Rehearsal deep breathing techniques in different ways. This technique of security is "deep breathing by calming down". The following are the procedures for implementation:

1) Participants are asked to take a relaxed position. The

2) participant must be sure of himself that he has relaxed with the position.

3) Count to four while breathing slowly. While inhaling through the nose, count from one to four, no need to rush or slowly.

4) Exercises with this count will help regulate your breath and concentrate on deep breathing. The stomach remains allowed to move forward and breathe using the diaphragm.

5) Hold your breath for seven seconds. In a relaxed and resistant state, do not pull or exhale for seven seconds. Participants can count it silently or use the hour.

6) Exhale for eight seconds. Slowly let the air out through the mouth during counting to eight. Calculating the length of time a person exhales will help the participant ensure that the length of the breath is twice the size, as a measure that the participant has breathed in optimally.

7) When you exhale, pull in the stomach to remove as much air as possible.

8) Repeat four breaths. Inhale again, hold it, then remove it entirely. Remember to keep counting so that the 4-7-8 ratio is always the same. After four breaths, participants will feel calm. Repeat this exercise for several breaths as needed.

After training or using this technique, participants are then asked to express their feelings in this way. Participants compare what was felt in the previous way. This technique is very possible to be repeated to get an eagle feeling and relax to everything that can trigger anxiety in the participants.

\section{d. Fourth}

session At the fourth session begins with creating a comfortable and relaxed atmosphere towards the activities to be carried out, the researcher conducts talks that can create a close emotional connection so that the participants are happy and focused on participating in this session. 
As with previous meetings, researchers reflected on the progress of the previous meeting. researchers and students explore feelings that are felt, changes and situations that occur after carrying out the previous session.

The researcher explores the students who complete the second challenge in their homes by checking the control card provided. Participants compare and see progress in themselves towards the feeling of anxiety in themselves. The control card that has been filled by students is used as a reflective material in expressing the feelings felt by students. The occurrence of these changes was due to regularly carrying out this exercise / rehearsal at home.

Then the researcher continued one exercise through the technique of approach Behavioral Rehearsal which is "Doing Breathing Techniques to Increase Energy" at this stage the steps taken are:

1) Sitting participants in an upright position. Sit using a chair with an upright back, then back against it.

2) Start by taking deep and long breaths several times. Inhale slowly and long, then exhale slowly as far as possible. Repeat at least four times, until you feel completely relaxed.

3) Pull and exhale through your nose quickly for 15 seconds. Shut your mouth and pull and exhale through your nose as quickly as possible, catching your breath quickly but deeply. This breathing must use diaphragmatic breathing, but you must draw and exhale as fast as you can. It would be better if participants put their hands on their stomachs to ensure that the stomach moves up and down during breathing. It's easier to do this exercise if you don't tighten the diaphragm as much as you can. Keep your head, neck and shoulders unmoving as long as your stomach expands and deflates.

4) Do 20 breaths. After a short rest, do another 20 breaths with the same technique. Pull and exhale through the nose, and make sure that you breathe using the diaphragm.

5) Do the third round of 30 breaths. This is the last part. Pull and exhale through the nose, making sure to breathe with a diaphragm.

In this session participants were again asked to do it at home like the challenges they had previously done. The researcher then describes the explanation as a motivation for the participants that they continue to do positive behavior and always see social conditions well, interact with the environment with normal feelings as a need to know the environment and others. Researchers encourage participants to guide themselves in implementing this technique in overcoming the problems faced. This activity was then ended and agreed for the next meeting.

\section{e. The fifth session}

At this meeting, a post test was given. The researcher explained the instructions for filling it out, as was done at the first meeting. After being filled in, the participants are then asked to collect the results of their work and the researchers would like to thank them for participating in the activity meeting so far.

\section{Descriptive Statistical Analysis}

Descriptivestatistical analysis was carried out to determine the influence of approaches Behavioral Rehearsal in dealing with students' social anxiety. The results of the research data were obtained from the data of students' social anxiety questionnaire in the group of students who had been given a behavioral rehearsal approach. The following is presented the pretest and posttest data on the application approach counseling Behavioral Rehearsal in dealing with students' social anxiety before and after treatment.

Table 4.1. Data on the level of social anxiety of students giving group counseling through the approach Behavioral Rehearsal for Results Experiment Groups Pretest and Post-test.

\begin{tabular}{|c|c|c|c|c|c|}
\hline \multirow{3}{*}{ Interval } & \multirow{3}{*}{$\begin{array}{c}\text { Activiti } \\
\text { es }\end{array}$} & \multicolumn{4}{|c|}{ Student Group } \\
\hline & & \multicolumn{2}{|c|}{ Pretest } & \multicolumn{2}{|c|}{ Postest } \\
\hline & & Frequency & Percentage & Frequency & Percentage \\
\hline $61-74$ & $\begin{array}{l}\text { Very } \\
\text { High }\end{array}$ & 2 & $20 \%$ & 0 & 0 \\
\hline $47-60$ & Height & 5 & $45 \%$ & 0 & 0 \\
\hline $33-46$ & Medium & 2 & $20 \%$ & 1 & $15 \%$ \\
\hline $19-32$ & Low & 1 & $15 \%$ & 6 & $50 \%$ \\
\hline $5-18$ & $\begin{array}{l}\text { Very } \\
\text { Low }\end{array}$ & 0 & $0 \%$ & 3 & $35 \%$ \\
\hline \multicolumn{2}{|c|}{ Total } & 10 & $100 \%$ & 10 & $100 \%$ \\
\hline
\end{tabular}

From the results of the percentage analysis, it was explained that before the group counseling with the behavior rehearsal approach there were 2 high categories or $20 \%$, high category 5 or $45 \%$ moderate category 2 people or $20 \%$ and low 1 person or $15 \%$ and after being given intervention as a guide trial there is 1 person who has decreased or $15 \%$ and 6 people in the low category or $50 \%$ and 3 people in the very low category or $35 \%$. So from this data, it can be seen that the level of social anxiety of students in the high category on the pretest results is relatively high. While the posttest results are in the low category, so the problem of social anxiety in students before and after being given treatment shows a very big change in overcoming social anxiety 


\section{CONCLUSION AND SUGGESTION}

\section{A. Conclusion}

From the results of the activity, it can be concluded that (1) the school experienced problems related to research studies, then the condition of the school and the maximum applied group counseling, especially using approaches and in school there were various social anxiety problems and group counseling activities were carried out with 5 sessions. (2) The results of the expert validation test stated that this guide was suitable to be used (3) the results of the percentage analysis explained that there was a decrease in value after the group counseling activities with a behavioral rehearsal approach.

It is advisable for school counselors to be able to make the guidelines produced in this study can be used as a reference in overcoming the same problems, then for teachers and principals to give special attention to $\mathrm{BK}$ teachers in service and to students who experience problems related to student social anxiety and are advised to researchers to develop the results of this research.

\section{REFERENCES}

Ali, M. \& Asrori, M. (2006). Psikologi Remaja: Perkembangan Peserta Didik. Jakarta: PT Bumi Aksara.

Elford, Brandle T. (2016). 40 teknik yang harus diketahui setiap konselor (edisi kedua) Pustaka Pelajar. Yogyakarta

Brown (2009). Group Counseling for elementary and middle school children. USA: Greenwood Publishing Group, Inc.

Borg, WD dan Gall, MD (2003). Educational Research, Second Edition. New York : Holt, Rinehart and Winston.

Corey, G. (2012). The Theory and practise of group counseling. 8rd ed. Pacific Grove, California: Books/Cole

Grecal, AM La, \& Lopezl, N. (1998). Social Anxiety AInong Adolescents : Linkages with Peer Relations and Friendships. Journal of Abnonnal Child Psycholog, 26(2), 83-94.

Hackney,H., \& Cormier, L. (2012). The professional counselor: A Process guide to helping (Edisi ke-7). Upper saddle River, NJ: Pearson Merrill.

Izzaty, dkk. (2008). Perkembangan Peserta Didik. Yogyakarta: UNY Press

Kerlinger, Fred N. (2003). Asas-Asas Penelitian Behavioral (Penerjemah, Landung S Simatupang) Editor H_J Koesoemanto. Yogyakarta: Gajah Mada University Press.

Kurnanto,M.Edi. (2013). Konseling Kelompok.Bandung; Alfabeta

Nurihsan, Juntika, A. Yusuf, Syamsu. (2010) Landasan Bimbingan dan Konseling. Bandung: PT. Remaja Rosdakarya.
Moshman, D. (2005). Adolescent Psychological Developmental: Rationality, Morality and Identity (Second). Mahwah, New Jersey, London: Lawrence Earlbaum Associates Publisher.

Muhari, DRR \&. (2013). Disiplin Siswa Di Sekolah Kelas XI Pemasaran 3 SMK Negeri 4 Surabaya. Jurnal BK UNESA, 4(1), 79-85.

Mutahari, H. (2016). Hubungan Antara Kepercayaan Diri Dengan Kecemasan Sosial Pada Siswa. E-Journal Bimbingan Dan Konseling, 3(5), 13-23.

Naugle dan Maher (2008). Modeling and Behavioral rehearsal. Dalam W.O'Donohue,JE Fisher, \& SC Hayes (Eds), Cognitive behavior therapy: Applying empirivally supported techniques in your practice (Edisi ke-2). New York, NY: John Wiley \& Sons

Stefan G. Hofmann, PMD (2010). Social Anxiety: Clinical, Developmental, and Social Perspectives, Second Edition (Second). London, United Kingdom: Academic Press, Elsevier.

Tirto Jiwo. (2012). Social Anxiety Disorder ( Social Fobia ), pp. 1-12.

Tuckman, WB (1999). Conducting educational research: Second Edition. USA: Harcourt Brace Jovanovich, Publisher.

Wijaya, RS (2014). Model Konseling Kelompok Eksistensial Humanistik Untuk Mengurangi Kecemasan Siswa Menentukan Arah Peminatan SMA Negeri Semarang. Jurnal Bimbingan Konseling, 3(2), 83-89.

Walsh,J. (2002). Shyness and social phobia. Health \& work, 27, 137-144

Winkel, WS dan Sri Hastuti. (2004). Bimbingan dan Konseling di Institusi Pendidikan. Yogyakarta: Media Abadi

Widoyoko,E.Putro. (2016). Teknik Penyusunan Instrumen Penelitian. Yogyakarta. 